\title{
Article
}

\section{Access to Life-Saving Medicines and Intellectual Property Rights: An Ethical Assessment}

\author{
Schroeder, Doris and Singer, Peter
}

Available at http://clok.uclan.ac.uk/3159/

Schroeder, Doris ORCID: 0000-0002-3633-2758 and Singer, Peter (2011)

Access to Life-Saving Medicines and Intellectual Property Rights: An Ethical

Assessment. Cambridge Quarterly of Healthcare Ethics, 20 (02). pp. 279-289. ISSN 0963-1801

It is advisable to refer to the publisher's version if you intend to cite from the work.

http://dx.doi.org/10.1017/S0963180110000939

For more information about UCLan's research in this area go to http://www.uclan.ac.uk/researchgroups/ and search for <name of research Group>.

For information about Research generally at UCLan please go to http://www.uclan.ac.uk/research/

All outputs in CLoK are protected by Intellectual Property Rights law, including Copyright law. Copyright, IPR and Moral Rights for the works on this site are retained by the individual authors and/or other copyright owners. Terms and conditions for use of this material are defined in the policies page.

\section{CLoK}

Central Lancashire online Knowledge www.clok.uclan.ac.uk

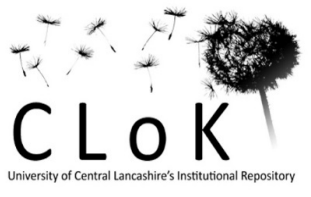




\title{
Access to Life-Saving Medicines and Intellectual Property Rights: An Ethical Assessment
}

\author{
DORIS SCHROEDER and PETER SINGER
}

Dying before one's time has been a prominent theme in classic literature and poetry. Catherine Linton's youthful death in Wuthering Heights leaves behind a bereft Heathcliff and generations of mourning readers. The author herself, Emily Brontë, died young from tuberculosis. John Keats' Ode on Melancholy captures the transitory beauty of 19th century human lives too often ravished by early death. Keats also died of tuberculosis, aged 25. "The bloom, whose petals nipped before they blew, died on the promise of the fruit" is how Percy Bysshe Shelley expressed his grief over Keats' death. ${ }^{1}$ Emily Dickinson wrote So Has a Daisy Vanished, being driven into depression by the early loss of loved ones from typhoid and tuberculosis. ${ }^{2}$

Today, tuberculosis is often understood as a disease that ended its blight on human lives in the Victorian Period. ${ }^{3}$ However, as noted in the introduction to this symposium, in 2008, 1.3 million people died from the disease, ${ }^{4}$ and the fight against it is certainly not over. In the context of access to medicines and intellectual property rights (IPRs), the contemporary example of tuberculosis can serve three purposes.

Access to life-saving medicines for the poor is hampered by many factors, of which the current intellectual property rights system is only one. Standardly available, low-cost, accurately prescribed antibiotics do not reach many tuberculosis sufferers in developing countries. This may be because of a shortage of doctors and nurses, a shortage of pharmacies, or the nonaffordability of even low-cost drugs to the poor (see also the diagram, "State of Health," in Klaus Leisinger's contribution to this symposium ${ }^{5}$ ). When patients follow the wrong treatment regimes or stop a course of antibiotics because they feel better and/or because they can no longer afford to continue the treatment, then drug-resistant strains of the bacillus emerge, leading to the second point.

Multidrug resistant strains of tuberculosis often cannot be cured by low-cost, first-line drugs but require second-line or third-line drugs. ${ }^{6}$ This is particularly true when tuberculosis occurs together with HIV/AIDS. As an example, one treatment that is well tolerated by sufferers of HIV-related tuberculosis, Mycobutin, is still under patent protection and is therefore priced beyond the reach of the poor. ${ }^{7}$ This leads to the access problem described in the introduction to the

This paper was written with support from the Commonwealth of Australia under the International Science Linkages program under grant agreement EF080010 in association with Innova-P2, funded by the European Community's Seventh Framework Programme grant number 217665. Special thanks to Thomas Pogge, whose ideas have influenced this article greatly. Thanks also to Julie Cook Lucas for comments on an earlier draft and to Cathy Lennon for research assistance. 


\section{Doris Schroeder and Peter Singer}

symposium: medicines are not affordable to the poor because of intellectual property rights protection.

Despite the high number of deaths worldwide, tuberculosis is still regarded as an orphan or neglected disease, illustrating what the symposium introduction terms the availability problem (i.e., that drugs are not developed for the health needs of the poor because incentives for pharmaceutical innovation are built around patients' ability to pay). Tuberculosis has recently been described as "the most deadly of 'neglected' diseases, ${ }^{\prime 8}$ and the European Commission has just granted orphan drug status to Rifapentine, a new tuberculosis drug, ${ }^{9}$ confirming that research on the disease has still not entered the mainstream.

In this article, we focus on the ways in which the access and availability problems of drugs are aggravated by the current intellectual property rights system. As quoted in the symposium introduction, it is estimated that 10 million people die every year because they do not have access to life-saving drugs. ${ }^{10}$

First we ask on what basis intellectual property rights might be justified even where they hamper access to drugs and the availability of medicines. We distinguish between natural right justifications and those based on social utility. After establishing that the natural right defense is unsuccessful, we compare three relevant situations with regard to their social utility: after the passage of the Trade-Related Aspects of Intellectual Property Rights Agreement (TRIPS; today), pre-TRIPS, and no IPR protection.

\section{Two Types of Social Rules}

Human communities are organized by social rules, many of which are encoded in law and administered through courts. Social rules may be understood in two main ways: they may reflect ultimate moral requirements, whether these are understood to be set down by God or our own innate moral sense, or dictated by reason; or they may be understood as serving a social purpose within human society.

The constitutional rights of individuals are typically understood in the first way, reflecting, as John Rawls says, a person's "inviolability founded on justice which even the welfare of society as a whole cannot override." ${ }^{11}$ The inviolability of these rights applies across the globe and across time, and they are often referred to as natural rights. ${ }^{12}$ The right not to be killed, suitably circumscribed (to allow for self-defense, for instance), is considered such a right. ${ }^{13}$ Traffic rules, on the other hand, are typically understood in the second way, in terms of their contextual social utility as facilitators of efficient travel. Such social rules are taken to be open to thoughtful revision in order to preserve or enhance their usefulness under changing conditions. By contrast, rules expressing natural-law requirements are considered to fall outside the power of societies to change.

The categorization of some social rules into one of these two categories is contested. Thus, some argue that the social rule against torture is based on expediency and may be revised or abolished in changed circumstances, whereas others present this rule as founded on a natural right. ${ }^{14}$

The social rules that create and define property rights are subject to similar contention: some assume that such rights should be designed to promote the common good, specified as economic efficiency, for instance, or poverty avoidance. ${ }^{15}$ Others, following John Locke, regard legal property rights as 
implementing preexisting natural rights to acquire things and to dispose of them as one pleases. ${ }^{16}$ The two disputant groups may entirely agree on what the rules should be and yet disagree profoundly on their justification.

\section{Are Intellectual Property Rights Natural Rights?}

The same disagreement as outlined regarding the topics of torture or property rights also exists with regard to IPRs. Some hold that IPRs should be shaped with an eye to the common good, striking the optimal balance between encouraging innovations and ensuring easy access to them. Others believe that innovators have a natural right to control the use of their innovation. This dispute was in evidence in the 1990s, when affluent states successfully pressured less developed states to accept the TRIPS agreement, which required them to legislate for very extensive IPRs.

Some argued that adopting U.S.-style IPRs would benefit poor countries by making them more innovative. Others argued that poor countries were morally required to adopt extensive IPRs in order to suppress the natural-law crimes of "theft," "piracy," and "counterfeiting" that were being committed by copycat manufacturers within their jurisdictions.

Which position is more defensible? Should IPRs be designed with social utility in mind or help realize creators' natural rights? One can offer three arguments against the latter, natural-law understanding of IPRs.

First, IPRs can be shaped in myriad ways, each specifying differently their mode of acquisition, scope, or duration. The most controversial debate in this context surrounds so-called patents on life. Whereas patents on complex living organisms, for example, pigs, ${ }^{17}$ are regularly granted in the United States, the Canadian Supreme Court has ruled that higher life forms cannot be patented within their jurisdiction. Hence, the famous oncomouse, patented in the United States by Harvard University applicants, does not fall under patent protection in Canada. ${ }^{18}$ Interestingly, the European Patent Office (EPO) at first rejected Harvard's patent application for the oncomouse, but later decided to grant the patent, arguing that benefits to humanity outweighed the harm to the mice. ${ }^{19}$ This means that the EPO granted the patent on grounds of social utility rather than the potential natural rights of the creators. The dispute is ongoing, given that the German Green Party together with a large group of organizations is currently lobbying the European Parliament to prohibit patents on higher life forms in Europe. ${ }^{20}$

Within this context, it is important to remember the historical starting point. Patents on life were originally regarded as incompatible with U.S. patent law in 1971, when the first case was considered. The now legendary Chakrabarty application (Ananda Chakrabarty had produced a genetically engineered bacteria that could clean oil spills) was first rejected by the U.S. Patent and Trademark Office. On appeal, the patent was granted by the Court of Customs and Patent Appeals by a three to two majority. On a second appeal by the U.S. Patent and Trademark Office to the U.S. Supreme Court, the patent was finally granted with a five to four majority. It is clear that opinions were split on this issue even in the United States. As Jeremy Rifkin has put it, this one case "laid the all-important legal groundwork for the privatization and commodification of the genetic commons. ${ }^{\prime 21}$ However, the above disagreement at supreme court level in several 


\section{Doris Schroeder and Peter Singer}

countries shows that it is certainly not obvious that patents on life are a natural right of inventors.

Second, like ordinary property rights, IPRs often clash with other important natural rights, such as the right to life. One of the best examples of this tension can be found in the area of access to life-saving medication, the topic of this article. As medicines under patent protection are priced under monopoly conditions, their invariably high markups make them unaffordable to poor patients. Given that IPR systems provide opportunities to stop generic producers from offering cheap copies of new drugs, no alternative sources of drug supply will be available to the poor, hence conflicting with, in the worst case scenario, their right to life. The question, simply put, is whether the creator of a life-saving medicine should have the legal authority to effectively deny this medicine to those who cannot afford it. (We return to this topic below).

Third, IPRs are not compatible with the natural-law understanding of property rights adduced to support them. By asserting an IPR in an innovation, the innovator claims not merely rights to the products made from their own materials but also new property rights over the same materials owned by others, who then lose their freedom to convert their materials into the same products. Such a deprivation of freedom conflicts with the natural-law understanding of property rights in material items, which protects owners against unilateral expropriation by others. If the rights one has to use one's own material property cannot be diminished by others without the owner's consent, then there can be no IPRs; that is, no innovator can unilaterally impose restrictions on what others are allowed to do with their own property.

An example ${ }^{22}$ : in 1995, the South African Council for Scientific and Industrial Research (CSIR) obtained a patent concerning the appetite suppressant properties of a Kalahari succulent, the Hoodia. Efforts at developing commercial products from the succulent are directed at the anti-obesity market. Since then, patents have been obtained in the United States, the United Kingdom, continental Europe, and Japan. Given the patent, the CSIR (or its sublicencees) can stop competitors from bringing their own Hoodia slimming product to market. This means, for instance, that impoverished communities in Namibia or local farmers are unable to use the Hoodia plants growing in their own territories for commercial gain within the anti-obesity market. As this is essentially the only viable commercial opportunity involving this succulent, it renders the plant worthless in terms of livelihoods. As a result, the property right in the physical plant, and with it the right to do with it as one pleases (e.g., to sell it for a specific purpose), has been taken away from the physical owners of the plant in favor of those holding intellectual property rights. ${ }^{23}$ One can see here that the common natural-law understanding of physical property rights-far from showing the way to an analogous natural-law understanding of IPRs-actually provides natural-law grounds against IPRs.

The above points throw sufficient doubt on the claim that creators have natural rights to the protection of their intellectual property. It is indeed unlikely that IPRs can be justified on natural law grounds. However, before we move on to the social utility defense, there is an important line of reasoning that we have not yet considered. Although natural law does not seem to support IPRs, is it possible that it might actually mandate against such rights? 


\section{Access to Life-Saving Medicines}

As this is not the place for a detailed excursion into natural law theory, we shall confine ourselves to its most prominent thinker ${ }^{24}$ : Thomas Aquinas (1225-1274). According to Aquinas, laws are the dictates of practical reason. Natural law is the rational, eternal order given to the universe by divine providence. Human beings, as rational creatures, are subject to natural law "in the most excellent way, in so far as ... [they] partake ... of a share of providence" through "an imprint on us of the Divine light." 25 This explains why natural law and natural rights are universal, according to Aquinas, independent of local, earthly traditions that may conflict with them. For him and his followers, natural law is "our intelligent participation in God's eternal law. ${ }^{\prime 26}$ It also explains why human beings can know or recognize what is required of them by the natural law. Given that they participate in eternal law as rational beings, they are able to identify ethical demands on themselves.

The main ethical demand on human beings, according to Aquinas, is that "good is to be done and pursued, and evil is to be avoided." In one's pursuit of the good, the most important element is the preservation of human life, or as Aquinas puts it:

Inasmuch as every substance seeks the preservation of its own being, according to its nature: and by reason of this inclination, whatever is a means of preserving human life, and of warding off its obstacles, belongs to the natural law. ${ }^{27}$

The protection of human life is therefore paramount for Aquinas, and the right to life is part of natural law. Another part of natural law is private property. According to Aquinas, "it is lawful for man to possess property" for three main reasons ${ }^{28}$ :

First because every man is more careful to procure what is for himself alone than that which is common to many or to all: since each one would shirk the labor and leave to another that which concerns the community. Secondly, because human affairs are conducted in more orderly fashion if each man is charged with taking care of some particular thing himself, whereas there would be confusion if everyone had to look after any one thing indeterminately.

Thirdly, because a more peaceful state is ensured to man if each one is contented with his own. Hence it is to be observed that quarrels arise more frequently where there is no division of the things possessed.

What then happens when the right to life collides with the right to property, for instance, if some have more than they need while others are starving? Or if some protect their intellectual property with the result that they are depriving the poor of life-saving medication? According to Aquinas, the right to life takes precedence over the right to property. For him:

Whatever certain people have in superabundance is due, by natural law, to the purpose of succoring the poor. ... Since, however, there are many who are in need, while it is impossible for all to be succored by means of the same thing, each one is entrusted with the stewardship of his own things, so that out of them he may come to the aid of those who are in need. Nevertheless, if the need be so manifest and urgent, that it is evident that the present need must be remedied by whatever means be at hand (for instance when a person is in some imminent danger, and there is no other possible remedy), then it is lawful for a man to succor his own need by means of another's property, by 
taking it either openly or secretly: nor is this properly speaking theft or robbery. ${ }^{29}$

In the natural law tradition following Aquinas, the right to property or intellectual property is therefore only valid as long as it does not interfere significantly with the right to life. Although Aquinas promotes the concept of property and hopes that the affluents' benevolence will help the poor, he supports the acquisition of another's property without their consent in situations of imminent danger to life.

This principle has been upheld by John Locke (1632-1704), one of the most eminent Western theorists on property rights. According to Locke:

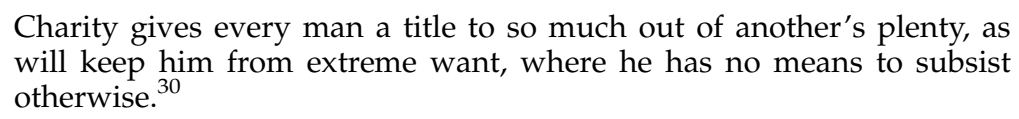

Charity gives every man a title to so much out of another's plenty, as will keep him from extreme want, where he has no means to subsist otherwise. $^{30}$

Does this mean that natural law mandates against intellectual property rights? It was noted in the symposium introduction that 10 million people are dying every year because of a lack of access to life-saving medicines and that this is partly because of the current IPR regime. Would this not suggest that natural law forbids IPRs or at least the current regime? No. The problem is more complex than this, as IPRs also save millions of lives every year, given that they provide incentives for pharmaceutical research. An assessment of the natural law compatibility of IPRs would therefore require the loss of lives to be higher than the number of lives saved. This is a calculation that is very difficult to make. However, there is a more ambitious demand that could be drawn from natural law theory that aligns better with the purpose of this article. Ideally, not only would the number of lives lost be lower than the lives saved, but the lives lost would be reduced to their utmost minimum. How this could be done requires an examination of the social utility of IPR systems, a task we now turn to.

\section{The Social Utility of Intellectual Property Rights}

Given our above conclusions on natural rights, IPRs have to be assessed by reference to the common good of humankind. In making this assessment, one must consider the effects of the system relative to those of its politically available alternatives. These effects depend on what the world is like: on present facts about resources and scarcity as well as on the present international economic order and distribution of wealth. Changes in the world may affect whether current IPR rules are justified, for example, the rule that gives monopoly pricing powers for 20 years to the creator of a life-saving second- or third-line tuberculosis drug.

\section{No IPR Protection}

In the context of IPRs, it is sometimes pointed out what the world might look like if we did not reward pharmaceutical innovations through patents. In such a world, it is unlikely that innovative pharmaceutical research would take place, at least as far as commercial companies were concerned. Their successful research efforts would almost invariably result in economic losses as soon as 
competitors, unrestrained by the IPR system, copied their inventions and offered the product at lower prices. Given that the competitors would not have to recoup the research and development costs, their prices would be much more attractive than the prices calculated to break even by the inventor. One can therefore argue that it is better to have medicines for the affluent now, which are likely to trickle down to the less affluent after the expiration of the monopoly period, than to have no medicines at all.

However, this comparison simplifies the problem beyond recognition. It is not sufficient to argue that the situation regarding access to life-saving medicines could be even worse. We could all be without access to drugs. An ethical assessment of the situation cannot focus exclusively on the worst possible scenario but must instead consider whether the current situation can be improved upon.

\section{The Pre-TRIPS Regime ${ }^{31}$}

Anand Grover clearly states that "TRIPS and FTAs have had an adverse impact on prices and availability of [generic] medicines." ${ }^{\prime 32}$ One possible comparison with the current situation is therefore the pre-TRIPS situation, which allowed states to decide how to protect and reward their pharmaceutical industries on the basis of their own interests.

An example ${ }^{33}$ : before 2005, Indian law only allowed patents on processes, not on products. As a result, India had a thriving generic pharmaceuticals industry that supplied cheap copies of patented medicines throughout the world's poor regions. However, in 1994 India signed up to TRIPS as negotiated in the Uruguay round of the General Agreement on Tariffs and Trade (GATT) treaty. Consequently, India was required to introduce patents on products by January 2005.

It is important here to remember that the poor currently face two problems when it comes to accessing life-saving drugs. First, because of the monopoly pricing powers granted to innovators for considerable lengths of time, they cannot afford medicines that are still under patent protection. The symposium introduction referred to this as an accessibility problem (i.e., medicines are priced beyond the reach of the poor). However, patent protection is not the only problem endangering poor people's health in the context of pharmaceutical innovation. Given that the pharmaceutical industry operates almost exclusively within the profit-making sector, diseases that primarily burden the poor are often not investigated in the first place. These diseases are referred to as "neglected diseases," because they are often ignored by the international research community. Hence, the second hindrance is the availability ${ }^{34}$ problem (i.e., drugs are not being developed for the needs of the poor). ${ }^{35}$

The main argument against the pre-TRIPS regime is that it did not stimulate the development of medicines for use in less developed countries. Given the lack of patent protection in countries such as Brazil, India, or South Africa, pharmaceutical companies could not rely on market exclusivity and were therefore unlikely to take potential profits in such markets into consideration when deciding upon research programs. Yet, these and other countries have considerable and increasing affluent subpopulations, which would be able to afford high drug prices. 


\section{Doris Schroeder and Peter Singer}

The argument in favour of the TRIPS regime with regard to developing countries is therefore twofold: first, it has the potential to awaken pharmaceutical interest in diseases that were hitherto not considered profitable in order to serve an affluent minority. Second, in the long run, TRIPS may bring benefits to developing countries as compared to the pre-TRIPS regime, in particular in the area of so-called type III diseases, that is, diseases that occur exclusively or overwhelmingly in poor countries. Pharmaceutical companies may well increase research into type III diseases, secure in the knowledge of strict patent protection and the prospect of achieving high monopoly prices from affluent patients, government agencies, and nongovernmental organizations (NGOs). And although access to such drugs may initially be confined to the more affluent, much larger numbers of people should be able to benefit from their existence in the long run, after the monopoly pricing interval has expired. It is too early, however, for success stories of this kind.

Thus, the current regime is likely to have advantages over its predecessor with regard to the availability problem (i.e., drugs are not being developed for the needs of the poor). However, these advantages must be weighed against problems regarding the accessibility problem (i.e., medicines are priced beyond the reach of the poor). It is in this area that the pre-TRIPS regime has clear advantages.

Before the TRIPS Agreement was adopted, most of the less developed countries had weak intellectual property protections or none at all, which enabled them to produce or import cheap generic versions of medicines that were still under patent protection. Relative to pre-TRIPS, the current situation therefore imposes a serious loss on the poor by pricing out of their reach new medicines that they could previously have obtained at generic prices. ${ }^{36}$

It is difficult to estimate the relative effects of a set of social rules, that is, how various groups of people fare differently under these rules than they would fare if other rules, or none, existed. Moreover, decisions about the design of social rules are rarely such that one option is unambiguously worse than another, that is, worse for some and better for none.

However, the current situation is preferable for the population of affluent countries, who gain access to additional medicines that would not have existed without the additional market demand for patented medicines that is now anticipated from less developed countries. The comparison is more complex in the case of affluent minorities in less developed countries. They are better off with regard to the availability problem; some new medicines would not have existed without the TRIPS Agreement. At the same time, they are worse off with regard to the accessibility problem. Although they are able to afford high monopoly prices, they are no longer able to benefit from the low prices of generic medicines. On balance, however, it seems plausible to argue that the additionally created medicines for local health needs make up for the financial losses for those who can afford under-patent drugs.

The social utility of the poor, who cannot afford monopoly prices, is the most difficult factor to assess. The extension of strong intellectual property rights through TRIPS into less developed countries burdens the poor disproportionately, as they immediately lose access to generic copies of drugs that are still under patent protection. On the other hand, this extension of intellectual property rights may benefit the poor of the future, given that additional 
incentives are provided to address health needs in developing countries. Initially, poor people would not be able to afford such new medicines. However, they may benefit from purchases made on their behalf by aid agencies and governments, and eventually the relevant patents will expire and prices will drop to just above the marginal cost level.

The magnitude of these burdens and benefits is enormous, and decisions of social utility are difficult to make. Currently, as Anand Grover has pointed out, 10 million deaths per year can be attributed to lack of access to life-saving medicines ${ }^{37}$ with at least part of this problem due to TRIPS and high monopoly prices. The exclusion of the poor from access to advanced medicines will continue to exact a heavy toll of disease and death for the indefinite future. On the other hand, millions of people may survive or be healthy in the future, thanks to the predicted availability of generic medicines that are likely to result from TRIPS.

Human-rights-focused philosophers may argue that it is morally impermissible to cause severe harms, including deaths, to some poor people now for the sake of protecting millions of other poor people from similarly severe harms later on. Given only these two choices, they would therefore endorse the pre-TRIPS situation. Yet, one cannot be satisfied with such an outcome in view of all the harm that could be averted from so many future lives by stimulating new drug development. From a utilitarian perspective, one might therefore argue that the overall benefits of TRIPS might have the potential to outweigh the overall losses.

\section{Conclusion}

In this article, we have argued that intellectual property rights systems have to be designed with overall human well-being and flourishing in mind. They are not mandated to secure the natural rights of inventors to have their creations protected against the right to life of the poor.

The pre-TRIPS regime had certain advantages over the TRIPS regime. It allowed the production and distribution of cheap copies of patented drugs by generic manufacturers, mostly from India, South Africa, and Brazil. As a result, some poor patients had access to life-saving drugs that are no longer available to them today. Yet, the pre-TRIPS regime did not provide the pharmaceutical industry with incentives to consider neglected diseases, which occur mostly in developing countries. As a result, not even the affluent in developing countries had their health needs served. Both systems therefore show some social utility, but also room for improvement.

It is vital that considerable improvement on the current situation be made. Although deaths from diseases such as tuberculosis had to be accepted as part of life until the mid 20th century, this is no longer the case. Today, it is one of the stains on humanity's conscience that 10 million people die each year because of lack of access to life-saving drugs. Some may not have access to doctors or pharmacies; others may be so poor that they cannot afford even cheap generic drugs. Yet others die because they are unable to pay high monopoly prices for drugs in a world changed by the TRIPS agreement. In this context, we have previously endorsed Thomas Pogge's reform plan, the Health Impact Fund (HIF) ${ }^{38}$ The HIF was described in earlier issues of this publication ${ }^{39}$, and we would like to reiterate our support. It is, as the World Health Organization has established, ${ }^{40}$ a "promising proposal," and it is time to move from promise to reality. 


\section{Doris Schroeder and Peter Singer}

\section{Notes}

1. Shelley PB. Adonais: An Elegy on the Death of John Keats 1821; available at http://mural.uv.es/ sangis/adonais.htm (last accessed 26 Jul 2010).

2. Mamunes G. So Has A Daisy Vanished: Emily Dickinson and Tuberculosis. Jefferson, NC: McFarland \& Co; 2007.

3. See, for instance, Lawlor C. Consumption and Literature: The Making of the Romantic Disease. Basingstoke: Palgrave Macmillan; 2007. Lawlor examines the influence of tuberculosis on literature from the Renaissance to the Victorian Period.

4. World Health Organization. Tuberculosis, available at http://www.who.int/mediacentre/ factsheets/fs104/en/ (last accessed 31 Jul 2010).

5. Leisinger K. "Lifting all boats": Access to medicines and the pharmaceutical sector. Cambridge Quarterly of Healthcare Ethics, this issue, $\mathrm{xx}-\mathrm{xx}$.

6. Second-line drugs are usually more expensive than first-line drugs and are only used when the latter fail. Likewise, third-line drugs are used when second-line drugs fail.

7. The average online price for the drug in Germany is $\epsilon 501$ for 90 tablets[0]; see http://www. chirurgie-portal.de/medikament/mycobutin-90-st-pfizer-pharma-gmbh-pzn-8669665.html.

Because the dosage may vary, it is not possible to say how long 90 tablets will last. However, tuberculosis treatment usually lasts six months and Mycobutin is one of the drugs that can be taken throughout; see http://www.netdoctor.co.uk/infections/medicines/100001775.html.

8. Agence France Press. Tuberculosis most deadly of infectious diseases. May 2010; available at http:/ /www.physorg.com/news193432561.html (last accessed 27 Jul 2010).

9. Sanofi-Aventis press release. Rifapentine is granted orphan drug status by European commission for treatment of tuberculosis. July 2010; available at http://en.sanofi-aventis.com/binaries/ 20100701_RIFAPENTINE_en_tcm28-28921.pdf (last accessed 27 Jul 2010).

10. Grover A. Promotion and Protection of all Human Rights, Civil, Political, Economic, Social and Cultural Rights, Including the Right to Development, a Report of the Special Rapporteur on the Right of Everyone to the Enjoyment of the Highest Attainable Standard of Physical and Mental Health, 2009, United Nations, A/HRC/11/12, p.6, 7, 28; available at http://www2.ohchr.org/english/bodies/hrcouncil/docs/ 11session/A.HRC.11.12_en.pdf (last accessed 31 Jul 2010).

11. Rawls J. A Theory of Justice. Cambridge, MA: Harvard University Press; 1999:3.

12. Brown BF, ed. The Natural Law Reader. New York: Oceana Publications; 1960.

13. Finnis J. Natural Law and Natural Rights. Oxford: Clarendon Press; 1980:281.

14. Brecher B. Torture and the Ticking Bomb. Oxford: Blackwell Publishers; 2007.

15. See note 11, Rawls 1999.

16. Nozick R. Anarchy, State, and Utopia. New York: Basic Books; 1974.

17. Jentzsch C. Patent for a Pig: The Big Business of Genetics, a film, HTTV Production for WDRWestdeutscher Rundfunk; 2006.

18. Canadian Environmental Law Association. Life Patents: The Oncomouse Case, not dated; available at http://www.cela.ca/collections/celacourts/life-patents-oncomouse-case (last accessed 27 Jul 2010).

19. Irwin A. Patent battle over life. Times Higher Education, 1995; available at http://www. timeshighereducation.co.uk/story.asp?storyCode $=95686 \&$ sectioncode $=26$ (last accessed $27 \mathrm{Jul}$ 2010).

20. Institute of Science in Society. Europe's uprising against GMOs and patents on life, 2009; available at http://www.i-sis.org.uk/EuropesUprisingAgainstGMOs.php (last accessed 27 Jul 2010).

21. Rifkin J. The Biotech Century: Harnessing the Gene and Remaking the World. New York: Jeremy P. Tarcher/Putnam; 1998:43.

22. Wynberg R, Chennells R. Green diamonds of the South: An overview of the San-Hoodia case. In: Wynberg R, Schroeder D, Chennells R, eds. Indigenous Peoples, Consent and Benefit Sharing. Berlin: Springer; 2009:89-124.

23. One might argue that the issue is actually much more complex, given the restraints imposed on patent applicants by the Convention on Biological Diversity (CBD). However, this does not concern the clash between property and intellectual property rights under discussion. In fact, one could even argue that one of the main results of the CBD is that it prioritizes physical property rights over intellectual property rights by legislating for nonhuman genetic resources to fall under the national sovereignty of states. 


\section{Access to Life-Saving Medicines}

24. Murphy M. The natural law tradition in ethics. In: Stanford Encyclopedia of Philosophy, 2008, online resource; available at http:/ / plato.stanford.edu/entries/natural-law-ethics / (last accessed 27 Jul 2010).

25. Aquinas T. Summa Theologica: Of the Various Kinds of Law, 1947 [1274]; available at http:// www.sacred-texts.com/chr/aquinas/summa/sum229.htm (last accessed 27 Jul 2010).

26. May W. Contemporary perspectives on Thomistic natural law. In: Goyette J, Latkovic M, Myers R, eds. St. Thomas and the Natural Law Tradition. Washington, DC: The Catholic University of America Press; 2004:138-84, at p. 132.

27. Aquinas T. Summa Theologica: Of the Natural Law, 1947 [1274]; available at http://www.sacredtexts.com/chr/aquinas/summa/sum232.htm (last accessed 27 Jul 2010).

28. Aquinas T. Summa Theologica: Of Theft and Robbery, 1947 [1274]; available at http://www. sacred-texts.com/chr/aquinas/summa/sum322.htm (last accessed 27 Jul 2010).

29. See note 28, Aquinas 1947 [1274].

30. Locke J. Two Treatises of Government, Book 1. London: Thomas Tegg, W. Sharpe and Son; 1823:31; available at http://socserv.mcmaster.ca/econ/ugcm/3ll3/locke/government.pdf (last accessed 27 Jul 2010).

31. This section draws heavily on Pogge T, Hollis A. The Health Impact Fund: Making New Medicines Accessible to All. Incentives for Global Health; 2008:52-4; available at http://www.yale.edu/ macmillan/igh/\# (last accessed 27 Jul 2010).

32. See note 10, Grover 2009:28.

33. From Pogge T, Schroeder D. Why we need a new approach to pharmaceutical innovation: A pragmatic answer to a moral question. In: Noppen M, Wynants M, eds. In Sickness and Health: The Future of Medicine. Brussels: Vrije Universiteit Brussel Press; 2009:197-213, at p. 202.

34. Grover uses the term differently, in all likelihood referring to the nonavailability of generic drugs.

35. Selgelid M, Sepers EM. Patents, profits, and the price of pills: Implications for access and availability. In: Illingworth P, Schuklenk U, Cohen JC, eds. The Power of Pills: Social, Ethical and Legal Issues in Drug Development, Marketing and Pricing Policies. London: Pluto Press; 2006:153-63, at p. 153.

36. Schroeder D. Does the pharmaceutical sector have a coresponsibility to secure the human right to health? Cambridge Quarterly of Healthcare Ethics, this issue, $\mathrm{xx}-\mathrm{xx}$.

37. See note 10, Grover 2009.

38. Incentives for Global Health Web site available at http://www.yale.edu/macmillan/igh/ (last accessed 27 Jul 2010).

39. Pogge T. The Health Impact Fund: Boosting pharmaceutical innovation without obstructing free access. Cambridge Quarterly of Healthcare Ethics 2009;18(1):78-86. Pogge T. The Montréal Statement on the Human Right to Essential Medicines. Cambridge Quarterly of Healthcare Ethics 2007;16:97108.

40. Pang T. Developing Medicines in Line with Global Public Health Needs: The Role of the World Health Organization. Cambridge Quarterly of Healthcare Ethics, this issue, $\mathrm{xx}-\mathrm{xx}$. 